\title{
RESEARCH AND HIGHER EDUCATION IN ECONOMICS: CAN WE DELIVER THE LISBON OBJECTIVES?
}

\author{
Jacques H. Drèze \\ CORE and Université Catholique de \\ Louvain
}

\author{
Fernanda Estevan \\ CORE and Université Catholique de \\ Louvain
}

\begin{abstract}
Can European economics become "the most dynamic and competitive in the world"? Using readily accessible data, this paper documents the following aspects. (i) Today, the United States outperforms Europe by a factor of the order of 3, with no clear trend; the Lisbon goal is not in sight. (ii) Europe is not homogeneous; the United Kingdom and the small countries in north central Europe significantly outperform the Big 4 continental countries (France, Germany, Italy, Spain); we conclude that the Big 4 should accept English as the lingua franca of economics and implement major institutional reforms. (iii) Some 35 leading economics departments (a dozen from each of these three areas) account for $75 \%$ of Europe's research output. (iv) The concentration of research in leading departments is substantial but not exclusive; it is comparable in Europe and the United States, but leading U.S. departments have incomparably more resources and also benefit from access to an integrated labor market. (v) Few PhD programs are of efficient size, especially in Europe, so further concentration is needed. (vi) Second-best funding of higher education calls for block grants to efficient programs; in Europe, these should be organized at the EU level. We conclude with a modest proposal (€15 million per year) consisting of block grants to leading departments and to young academic researchers. Our optimistic verdict is that substantial progress toward the Lisbon goal is in sight, but it requires significant departures from current practices. (JEL: I21, I23)
\end{abstract}

\section{Introduction}

The Lisbon objectives aim to make the European Union "the most dynamic and competitive knowledge-based economy in the world," through education, research, and development. Although the primary concern lies with achievements in science and technology, economics is also at stake: economic policies in the

\footnotetext{
Acknowledgments: This lecture was delivered by Jacques H. Drèze in a special session on Research and Higher Education in Economics. We thank David Colander, Jean-Jacques Herings, François Maniquet, and an anonymous referee for helpful remarks on a previous draft, and we thank Jacques Cremer, Mathias Dewatripont, and Andreu Mas-Colell for their public discussion of this paper. We also record our intellectual debt to Cremer and Gérard-Varet (1999). We retain sole responsibility for the views expressed here.
}

E-mail addresses: Drèze: dreze@core.ucl.ac.be; Estevan: estevan@core.ucl.ac.be 
Union should undoubtedly reflect the most advanced developments of the discipline. This calls for (i) first-rate education of economists working not only at our universities but also at the European Commission and in other services; and (ii) first-rate research, both applied and fundamental, on the policy problems faced by the Union. Also, understanding the requirements of excellence in economic education and research may lead to conclusions of relevance for similar achievements in other disciplines closer to science and technology.

This paper looks at research and higher education in economics in Europe today, and it attempts to evaluate them with respect to (i) the objective of being "the most dynamic and competitive in the world" and (ii) the aims of the European Economic Association (EEA), as stated in Article 2 of its statutes: "to contribute to the development and applications of economics as a science in Europe; and to improve communication and exchange between teachers, researchers and students in economics in the different European countries."

This paper does not rely on systematic and extensive research. Rather, it reflects a personal assessment of the issue and of avenues toward improvement that are also based on personal experience (more than 48 years in Drèze's case). In the process of organizing our thoughts, we were led to check a variety of readily available data, which suggested new and interesting conclusions beyond the confirmation of received ideas. Unfortunately, the data are scanty; it would be desirable to extend the information base. We nonetheless feel confident in concluding that major progress is in sight if suitable policies are adopted - especially in the large continental countries but also at EU level.

The paper is organized as follows. Sections 2-6 review data on research performance in Europe and the United States, leading to a preliminary conclusion in Section 7. Section 8 deals with doctoral education, and Section 9 reviews the upstream issue of funding doctoral training and research. This leads to a proposal in Section 10. A brief summary (Section 11) concludes the paper. ${ }^{1}$ The upstream issue of how to measure performance is dealt with in Appendix A, which is complemented by Appendix B on sources. ${ }^{2}$

\section{European Economics in the World}

Table 1 presents some summary statistics aimed at providing a comparative picture of recent economic research accomplishments: Nobel prizes, Econometric Society Fellowships, citations, and publications. These four measures are listed in

1. The summary and conclusions are self-contained and provide at a glance an overview of the paper.

2. Readers not familiar with our sources and eager to assess the evidence rigorously may find it helpful to look at these appendices forthwith. 
TABLE 1. Europe versus U.S. in the world.

\begin{tabular}{|c|c|c|c|c|c|}
\hline & Europe $^{a}$ & U.S. & U.S./Europe & $\begin{array}{l}\text { Europe in } \\
\text { the world }(\%)\end{array}$ & $\begin{array}{l}\text { U.S. in the } \\
\text { world }(\%)\end{array}$ \\
\hline Nobel laureates ${ }^{b}$ & 14 & 41 & 2.9 & 23 & 67 \\
\hline Fellows ES, $2005^{\mathrm{c}}$ & 124 & 408 & 3.2 & 21 & 68 \\
\hline $\begin{array}{l}\text { Publications, KMS, } 500 \\
\text { economists }\end{array}$ & 47 & 390 & 8.3 & 9 & 78 \\
\hline \multicolumn{6}{|l|}{ Citations $^{\mathrm{d}}$} \\
\hline Who's Who IV & 107 & 534 & 4.8 & 15 & 72 \\
\hline $\begin{array}{l}\text { Coupé, } \\
\text { Departments }\end{array}$ & 46,954 & 229,180 & 4.9 & 16 & 76 \\
\hline $\begin{array}{l}\text { Coupé, } \\
500 \text { economists }\end{array}$ & 13,953 & 81,390 & 5.8 & 13 & 78 \\
\hline \multicolumn{6}{|l|}{ Publications, pages ${ }^{\mathrm{d}}$} \\
\hline KMS & 10,084 & 31,265 & 3.1 & 21 & 65 \\
\hline $\begin{array}{l}\text { Coupé, } \\
\text { Departments }\end{array}$ & 301,305 & 761,478 & 2.5 & 24 & 61 \\
\hline $\begin{array}{l}\text { Coupé, } \\
500 \text { economists }\end{array}$ & 55,758 & 104,139 & 1.9 & 26 & 50 \\
\hline
\end{tabular}

${ }^{\text {a }}$ Our definition of Europe corresponds to EU 15 plus Norway, unless specified otherwise.

${ }^{\mathrm{b}}$ According to affiliation at time of award.

${ }^{\mathrm{c}}$ According to affiliation as listed in Econometrica (2006), vol. 74(3).

${ }^{\mathrm{d}}$ See Appendix B for interpretation and references.

decreasing order of selectivity. ${ }^{3}$ In spite of substantial discrepancies reflecting the underlying definitions, the message of Table 1 is clear: Europe's research output amounts to some $15 \%$ to $25 \%$ of world output, versus $60 \%$ to $75 \%$ for the United States. The U.S.-Europe gap is thus substantial. As stated, the Lisbon objective is not in sight for economics.

Table 2 introduces a time perspective based on whatever data we could readily find. Looking at citations and publications, no clear trend emerges; $;{ }^{4}$ but for Nobel laureates and ES Fellows, ${ }^{5}$ the U.S. lead is increasing. It is conceivable that more refined data would reveal some trend, ${ }^{6}$ but it is unlikely that such a trend would be quantitatively significant.

The data from Who's Who in Table 2 contrast the countries of residence (i.e., academic affiliation) and countries of birth, across the three successive editions. The table reveals that the United States uniformly attracts more top economists than are born there: a "brain drain" is evident. Table 3 (based on edition IV) confirms that well-known phenomenon with precision. From Table 3 a we observe that 153 economists in the set (585-432; i.e., a full 26\%) moved from a first degree

3. See Appendix A for a concise discussion of the rationale behind these measures; see Appendix B for sources and definitions. See also note 54 for an interpretation of the notion of "selectivity."

4. The number of European economics departments ranked among the top 100 in the world did double between 1980 and the mid 1990s (data from Hirsch et al. 1984; hereafter HABM). But for citations (Who's Who data), no clear trend emerges.

5. Drèze confesses some puzzlement at the sharp rise in the U.S. share of ES Fellowships!

6. Some annual data from the 1990s appear in European Commission (2004). 
TABLE 2. Europe versus U.S. over time.

\begin{tabular}{|c|c|c|c|c|c|c|}
\hline & & Europe & U.S. & U.S./ Europe & $\begin{array}{c}\text { Europe in } \\
\text { the world } \\
(\%)\end{array}$ & $\begin{array}{l}\text { U.S. in } \\
\text { the world } \\
(\%)\end{array}$ \\
\hline \multirow[t]{2}{*}{ Nobel laureates } & 1969-1989 & 11 & 15 & 1.4 & 41 & 58 \\
\hline & 1990-2005 & 3 & 26 & 6.7 & 13 & 87 \\
\hline \multirow[t]{2}{*}{ Fellows ES } & Jan 1981 & 88 & 179 & 2.0 & 28 & 56 \\
\hline & 2005 & 124 & 408 & 3.2 & 21 & 68 \\
\hline \multicolumn{7}{|l|}{ Who's Who II } \\
\hline by affiliation & $1972-1983$ & $24 \%$ & $67 \%$ & 2.8 & 24 & 67 \\
\hline by birth & $1972-1983$ & $32 \%$ & $55 \%$ & 1.7 & 32 & 55 \\
\hline \multicolumn{7}{|l|}{ III } \\
\hline by affiliation & 1984-1996 & $28 \%$ & $60 \%$ & 2.1 & 29 & 60 \\
\hline by birth & 1984-1996 & $39 \%$ & $43 \%$ & 1.1 & 39 & 43 \\
\hline \multicolumn{7}{|l|}{$I V$} \\
\hline by affiliation & 1990-2000 & $13 \%$ & $69 \%$ & 5.3 & 13 & 69 \\
\hline by birth & 1990-2000 & $15 \%$ & $64 \%$ & 4.3 & 15 & 64 \\
\hline Number of departments & 1978-1982 & 11 & 76 & 6.9 & 11 & 76 \\
\hline (based on & 1990-2000 & 19 & 70 & 3.7 & 19 & 70 \\
\hline $\begin{array}{l}\text { publications, } \\
\text { HABM) })^{\mathrm{a}}\end{array}$ & $1996-2000$ & 22 & 66 & 3.0 & 22 & 66 \\
\hline
\end{tabular}

${ }^{\text {a}}$ Based on Table 3 in Coupé (2003). The ranking of economics departments by HABM for 1978-1982 was updated by Coupé for the 1990s; the original ranking is based on 24 journals.

elsewhere to a U.S. PhD. Thus, the attractiveness of U.S. doctoral programs plays a significant role in feeding the brain drain. Presumably, the attractiveness of U.S. PhDs reflects their quality; it is also enhanced by the use of English as the language of instruction. There is a useful lesson here for Europe.

Of course, Europe has benefited from the fact that some of its citizens did acquire a U.S. PhD: 66 economists listed in Who's Who IV did acquire a U.S. $\mathrm{PhD}$ after a first degree in Europe (Table 3a), and 26 of them are affiliated with European universities today (Table 3b). Although the "return" rate (40\%) is disappointing, that group is clearly relevant for European economics, especially in some countries. ${ }^{7}$

TABLE 3a. PhD versus first degree

\begin{tabular}{lcrcc}
\hline $\begin{array}{c}\text { PhD } \\
\text { First degree }\end{array}$ & Europe $^{\mathrm{a}}$ & U.S. & ROW $^{\mathrm{b}}$ & Total \\
\hline Europe & 90 & 66 & 6 & 162 \\
U.S. & 12 & 432 & 2 & 446 \\
ROW & 10 & 87 & 17 & 114 \\
Total & 112 & 585 & 25 & 722 \\
\hline
\end{tabular}

Note: There are 21 missing observations.

${ }^{a}$ Includes Switzerland.

${ }^{\mathrm{b}}$ Rest of the World.

Source: Blaug and Vane (2003).

7. Spain in particular-see Table 9 . 
TABLE 3b. Affiliation versus $\mathrm{PhD}$.

\begin{tabular}{lrrrrr}
\hline $\begin{array}{l}\text { Current affiliation } \\
\text { PhD }\end{array}$ & Europe $^{\mathrm{a}}$ & U.S. & ROW $^{\mathrm{b}}$ & Non-Academic & Total \\
\hline Europe & 67 & 36 & 3 & 7 & 113 \\
U.S. & 26 & 489 & 32 & 41 & 588 \\
ROW & 2 & 9 & 12 & 1 & 24 \\
Total & 95 & 534 & 47 & 49 & 725 \\
\hline
\end{tabular}

Note: There are 18 missing observations.

${ }^{\text {a } I n c l u d e s ~ S w i t z e r l a n d . ~}$

${ }^{\mathrm{b}}$ Rest of the World.

Source: Blaug and Vane (2003).

Today, it remains true that a U.S. PhD has value for Europeans. Young Europeans should be encouraged to study at the world's best universities. But Europe, too, should offer first-rate $\mathrm{PhD}$ education; it should facilitate and promote the return of its citizens trained in the United States.

\section{Looking Inside Europe}

\subsection{Europe Is Not Homogeneous}

Common wisdom has it that U.K. economics outperforms continental economics. Less widely appreciated is that continental Europe itself is not homogeneous. This fact is documented in Table 4, borrowed from Lubrano et al. (2003; hereafter LBKP). Looking at the last column of Table $4 \mathrm{~b}$, we note first ("Total") that European economists publish on average some $40 \%$ of their papers 8 in "national" journals, with no difference between the United Kingdom and the continent. ${ }^{9}$ The same column brings out the different publication habits between two groups of continental countries: 10 small ones (upper panel) versus the "Big 4" (B4: France, Germany, Italy, and Spain). Whereas economists in the small countries publish on average some $25 \%$ of their papers in major national outlets, those in the B4 publish the bulk (two-thirds or more, up to $85 \%$ in France) of their papers there.

For ease of comparison and for the sake of homogeneity, Table 5 uses a subgroup of 7 "small" countries (S7): Austria, Belgium, Denmark, Finland, the Netherlands, Norway, and Sweden. ${ }^{10}$ Their population adds up to 58.4 million, close to that of the UK (60 million) and to one-fourth that of the B4 (240 million). The overall message from Table 5 is unambiguously that the B4 stand well

8. Warning: these percentages refer to papers published in "major outlets" - that is, journals located above the median in the distribution of articles by journals. The data thus cover half the papers published, leaving out those scattered in "minor" (presumably mostly national) outlets.

9. Except, of course, that the United Kingdom's (UK's) national language is English!

10. This set is somewhat hybrid — in particular by not including Switzerland, which is not present in the LBKP data-adding Switzerland does not affect conclusions. 
TABLE 4a. Comparing countries' quantitative indicators.

\begin{tabular}{lrccccrr}
\hline Country & Articles & Journals & Authors & $\begin{array}{c}\text { Foreign } \\
\text { coauthors } \%\end{array}$ & $\begin{array}{c}\text { Population } \\
\text { (millions) }\end{array}$ & $\begin{array}{c}\text { Authors/ } \\
\text { popul. }\end{array}$ & $\begin{array}{r}\text { Econ. } \\
\text { dept. }\end{array}$ \\
\hline Austria & 842 & 247 & 460 & 15 & 8.1 & 56.67 & 12 \\
Belgium & 1,656 & 298 & 806 & 19 & 10.3 & 76.99 & 16 \\
Denmark & 919 & 253 & 463 & 14 & 5.4 & 85.74 & 8 \\
Finland & 713 & 174 & 433 & 16 & 5.2 & 83.27 & 18 \\
Greece & 861 & 245 & 403 & 16 & 10.9 & 36.76 & 12 \\
Ireland & 460 & 143 & 256 & 17 & 3.8 & 67.11 & 8 \\
Netherlands & 3,478 & 415 & 1,793 & 14 & 16.0 & 111.94 & 10 \\
Norway & 940 & 233 & 470 & 13 & 4.5 & 104.44 & 7 \\
Portugal & 260 & 117 & 144 & 25 & 10.0 & 14.40 & 15 \\
Sweden & 1,652 & 304 & 868 & 12 & 8.9 & 97.42 & 21 \\
France & 5,118 & 397 & 2,698 & 17 & 59.2 & 46.00 & 70 \\
Germany & 4,191 & 406 & 2,506 & 13 & 82.2 & 30.19 & 98 \\
Italy & 3,545 & 355 & 1,921 & 14 & 57.8 & 32.87 & 72 \\
Spain & 2,338 & 307 & 1,527 & 14 & 39.8 & 38.37 & 48 \\
UK & 13,351 & 613 & 6,656 & 15 & 60.0 & 115.60 & 96 \\
Total & 40,324 & 681 & 21,406 & - & 382.1 & 56.02 & 511 \\
California & 7,893 & 560 & 3,419 & 19 & 33.9 & 100.86 & 52 \\
\hline
\end{tabular}

Source: LBKP (p. 1378, Table 4).

below par in any per capita comparison. Actually, nowhere do they significantly outperform either of the other two groups even in absolute terms, in spite of the 4-to-1 population ratio! ${ }^{11}$

In the last two rows of Table 5, the B4, the S7, and the UK are close to parity in absolute terms, implying a huge deficit of the B4 per capita. This statement, which we offer as a summary picture of regional disparities in Europe, has two aspects:

1. The S7 do just as well as the UK, thus moderating the view that continental economics lags behind the UK. ${ }^{12}$

2. The B4 lag substantially behind the $\mathrm{S} 7$ as well as the UK. ${ }^{13}$

\subsection{Why Do the B4 Lag Behind?}

The B4 do indeed lag markedly behind the S7 in per capita terms, which are appropriate here. Table $4 \mathrm{~b}$ has already suggested one explanation: The B4 economists

11. The first column of Table 4a credits B4 economists with 15,192 articles (all outlets combined), versus 10,200 for the S7 and 13,351 for the UK. In Table 5, although top economists in the B4 publish more (in absolute terms) than those in the S7, still they publish less than top economists in the UK.

12. Also moderating the importance of English as the native language.

13. Curiosum: The set of 200 leading universities worldwide published in the Times Higher Education Supplement of October 6, 2006, contains 18 entries for the B4, 28 for the S7, and 29 for the UK. 
TABle 4b. Publication characteristics.

\begin{tabular}{lcccccc}
\hline & \multirow{2}{*}{$\begin{array}{c}\text { Journals } \\
\text { used }\end{array}$} & $\begin{array}{c}\text { Major } \\
\text { outlets }\end{array}$ & Top & Articles \% & National & Articles \% \\
\hline Austria & 247 & 39 & 11 & 24 & 1 & 6 \\
Belgium & 298 & 45 & 18 & 32 & 3 & 26 \\
Denmark & 253 & 28 & 11 & 29 & 1 & 30 \\
Finland & 174 & 12 & 4 & 17 & 2 & 53 \\
Greece & 245 & 32 & 3 & 6 & 6 & 25 \\
Ireland & 143 & 12 & 2 & 8 & 2 & 63 \\
Netherlands & 415 & 46 & 20 & 41 & 1 & 8 \\
Norway & 233 & 30 & 10 & 37 & 2 & 13 \\
Portugal & 117 & 18 & 9 & 39 & 1 & 27 \\
Sweden & 304 & 31 & 9 & 30 & 2 & 15 \\
France & 398 & 13 & 3 & 11 & 10 & 85 \\
Germany & 406 & 22 & 5 & 11 & 11 & 66 \\
Italy & 355 & 24 & 3 & 7 & 17 & 81 \\
Spain & 307 & 16 & 7 & 23 & 7 & 67 \\
United Kingdom & 613 & 51 & 9 & 20 & 27 & 40 \\
Total & 681 & 247 & 47 & 17 & 93 & 40 \\
California & 560 & 64 & 36 & 66 & 1 & 2 \\
\hline
\end{tabular}

Source: LBKP (p. 1381, Table 6).

publish mostly in national journals in national languages. This is much less the case for the S7, where economists publish more in English and in top journals.

Of course, there is nothing wrong with publishing in national journals, especially when the papers deal with issues of specific national interest or are addressed

TABLE 5. Looking inside Europe.

\begin{tabular}{lrrr}
\hline & Big 4 & Small $7^{\mathrm{b}}$ & U.K. \\
\hline Population (million) & 240 & 58,4 & 60 \\
Fellows ES & 49 & 26 & 48 \\
Who's Who III & 61 & 28 & 165 \\
Who's Who IV & 25 & 21 & 59 \\
Coupé & & & \\
Citations & 5,591 & 13,005 & 28,358 \\
$\quad$ 200 Departments & 4,098 & 3,152 & 6,703 \\
$\quad$ 500 Economists & & & \\
Publications pages & 73,914 & 83,078 & 142,209 \\
$\quad$ 200 Departments & 20,553 & 9,909 & 24,943 \\
$\quad$ 500 Economists & & & \\
KMS & $3,745^{\mathrm{c}}$ & 3,472 & 3,759 \\
Publications pages & & & \\
$\quad$ 120 Departments Europe & 10,947 & 12,432 & 11,015 \\
LBKP & & \\
Publications pages & & \\
$\quad$ Top journals & &
\end{tabular}


specifically to a national audience. But otherwise the implication of limited readership is unavoidable. Also, the international journals privileged by authors in different countries may differ. To illustrate: the French Comité National de la Recherche Scientifique (CNRS) publishes regularly a classification of leading journals based on peer opinions. The 2004 issue lists 57 leading journals in "general economics"; of these, 40 do not appear among the 68 "top journals" selected by LBKP. Conversely, 51 of the 68 LBKP top journals are not on the CNRS list. ${ }^{14}$

One normative conclusion would be: It is high time that a majority of B4 economists wake up to the fact that English is the undisputed lingua franca of economics! (Of course, there exists in each B4 country a minority of economists and institutions that are well aware of this and act accordingly. ${ }^{15}$ )

Waking up could, and perhaps should, ${ }^{16}$ take various forms:

a. Write and publish in English, so as to reach the whole profession and not merely the minority of colleagues who read your national language.

b. Taking this argument to the limit, issue your better national journals in English, as done recently by the German Economic Review. ${ }^{17}$

c. Introduce English as the basic language of your $\mathrm{PhD}$ programs in order to attract foreign students as well as teachers.

d. Encourage PhD students to write (and publish, where possible) their dissertations in English.

For a small sample of universities for which such information was readily available on the World Wide Web, the percentage of dissertations listed with an English title for the period 1994-2003 is as follows: Paris I (ETAPE), 0\%; Toulouse (GREMAQ), 12\%;18 Alicante, 40\%; Erasmus-Rotterdam, 65\%; Université Catholique de Louvain, 94\%; Autonoma-Barcelona, 100\%; European University Institute, $100 \%$.

14. It is interesting that only 7 French journals appear on the CNRS list.

15. The figures in Table $4 \mathrm{~b}$ concern all economists and "major outlets." Tables 7 and 10 in LBKP give measures of publications by members of 75 leading European departments in the 681 Journal of Economic Literature journals and in the top 68 LBKP journals, respectively. Counting articles, the latter figures represent $62 \%$ of the former, with $R^{2}=0.875$. Thus, concentration in national outlets is well below average among members of leading departments, who publish $62 \%$ of their articles in top international journals.

16. Should: as argued in Section 7.

17. A few continental journals had adopted English from the start (e.g., Kyklos and Scandinavian Journal); several others publish papers in both English and a local language (e.g., Annales d'Economie et de Statistique and Recherches Economiques de Louvain; interestingly these two journals rank above all other French-titled journals in the CNRS classification).

18. In addition, some $20 \%$ contain at least one English chapter. 
The adoption of English matters not only for communication with the rest of the world, it is also essential for communication and exchange within Europe; that is, for implementing the aims of the EEA. ${ }^{19}$

But there is another hypothesis worthy of attention: the university systems in the B4 are inefficient, rigid, and outmoded; in particular, they fail to provide incentives for research that are comparable to those prevailing in the UK and the S7. It may sound improper for outsiders to say so, but isn't this view shared by most of us? How many complaints have we heard about the French concours d'agrégation, the Italian concorso, the German and Spanish habilitation, or the German lehrstuhl (chair) system? Our Table 5 translates these widely held views into objective, quantitative terms. We are simply observing that the emperor is naked. (Of course, a number of institutional reforms have been introduced recently, the effects of which are not yet reflected in data for the 1990s. Tracing these reforms and their impact belongs on the research agenda.)

\subsection{Progressing Toward Lisbon}

The relevance of the proposed diagnostic for the Lisbon program is clear: If the B4 achieved the same research output per capita as the S7, then European output would be doubled and the U.S./Europe output ratio would drop from the current $3 / 1$ to an acceptable 3/2. This sets a clear intermediate goal on the Lisbon road. There seem to exist no objective reasons why this could not be accomplished. Even if the Lisbon objective as such is not in sight, major progress is at hand. Of course it will take time, but the direction is clear: Adopt English and reform institutions!

The realism of this suggestion is clearly illustrated by the record of some countries, in particular the Netherlands (a country that stands out in Table 4) and Spain. ${ }^{20}$ Twenty-five years ago, no Dutch department appeared among the 143 top entries of the HABM survey; ${ }^{21}$ today, six Dutch departments would make it! $!^{22}$ The recent development of economic research in the Netherlands has indeed been spectacular; pioneered by the Econometric Institute 50 years ago, it was fed more recently by such initiatives as CentER in Tilburg and the Tinbergen Institute bringing together three universities from Amsterdam and Rotterdam. Similarly, although no Spanish department appeared in the HABM survey, at least three would make it handsomely today (Autonoma, Carlos III, and Pompeu Fabra), a reflection of recent initiatives. A lot can be accomplished in a rather short time if one uses the right means!

19. Note that English has always been the sole language recognized by the EEA, in particular for papers published in the association's journal or presented at EEA congresses.

20. Recent developments in Spain are discussed in detail by Ruiz-Castillo (2006).

21. See note (a) to Table 2.

22. See Table 2 in Coupé (2003). 
We do not offer here specific suggestions for institutional reforms: that would require detailed familiarity with national systems. But the direction of reform is clear: introduce research incentives for individuals and quality incentives for departments.

\section{Distribution of Research Output over Departments}

Figures 1 and 2, based on data by departments from Coupé (2003 and Web page) pertaining to the ECONLIT journals for the period 1990-2000, give the cumulative distribution of publications for European and U.S.-based authors, respectively.

If the underlying distribution obeyed the popular law of Zipf (1949), whereby size is inversely proportional to rank, then the log-log graphs should be straight lines. That law has been found applicable to the size distribution of firms and cities. The law does not apply to economics departments, and it is easy to understand why: There are no "giants" among departments, so the upper tail of the distribution is flatter than required to fit the bulk of the distribution; this is quite natural. Yet the log-data are nearly collinear over the bulk of the observations, so the degree of

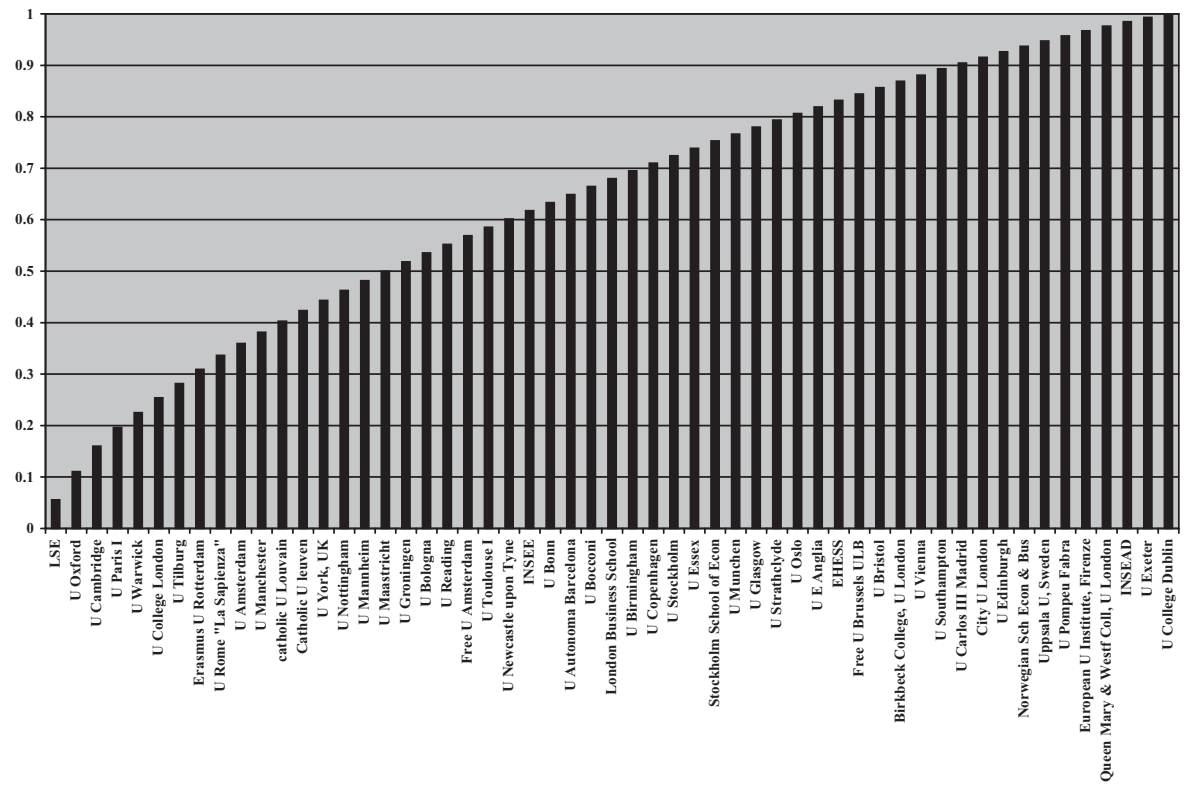

FIGURE 1. Cumulative distribution of publications (pages) in European economics departments.

Note: There are 55 European departments in the sample (of the 200 most prominent economics departments) that amount to 301,305 pages of publications.

Source: Based on data provided by Tom Coupé for publications in ECONLIT and WEB OF SCIENCE journals in the period 1990-2000. 


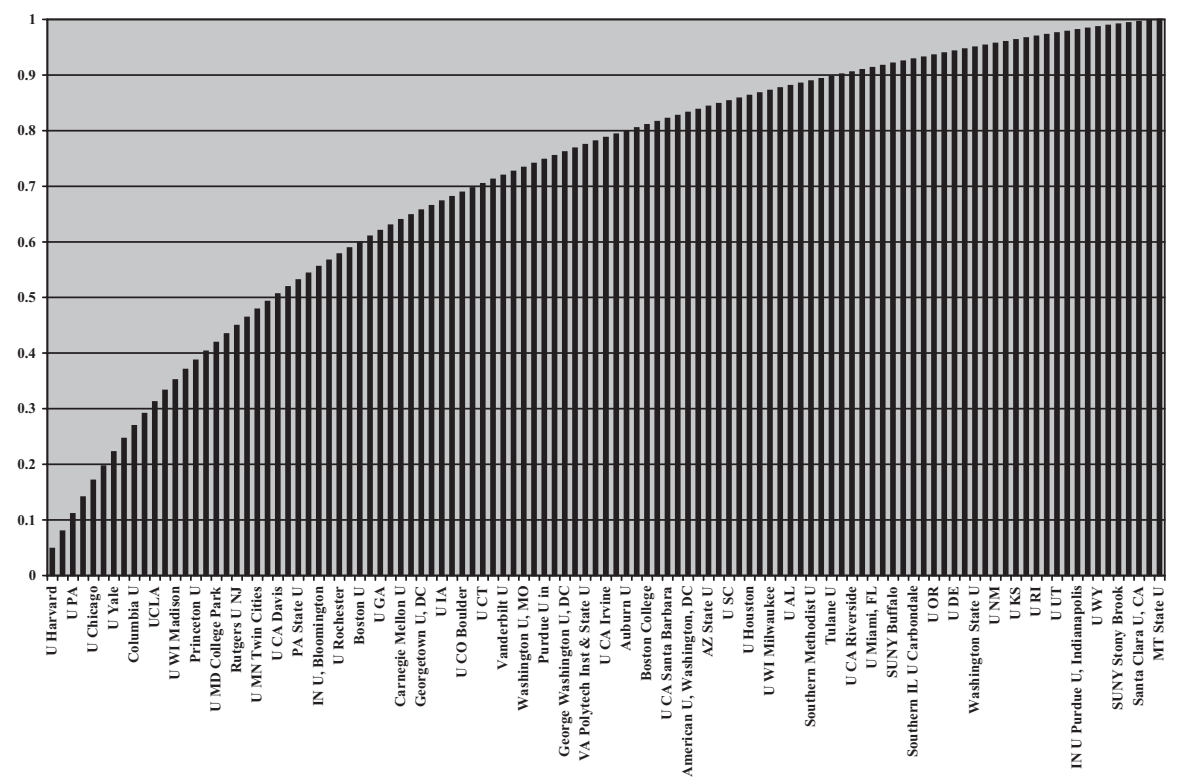

FIGURE 2. Cumulative distribution of publications (pages) in American economics departments.

Note: There are 109 American departments in the sample (of the 200 most prominent economics departments) that amount to 761,478 pages of publications. Due to lack of space, only one of every two labels appears in the graph. The 20 first American departments are: Harvard, Berkeley, Pennsylvania, Stanford, Chicago, Ann Arbor, Yale, MIT, Columbia, Northwestern, UCLA, NYU, Madison, Cornell, Princeton, Illinois, Maryland, Duke, Rutgers, Ohio State.

Source: Based on data provided by Tom Coupé for publications in ECONLIT and WEB OF SCIENCE journals in the period 1990-2000

concentration at the top in Figures 1 and 2, though substantial, is neither surprising nor excessive.

According to Figure 2, 23 departments account for $50 \%$ of the publications emanating from the 111 U.S. departments covered, versus 17 out of 55 departments in Europe. The message of these data is clear: in both the United States and Europe, half the research output is concentrated in some 20 top universities, but the other half is spread over a number of rank-and-file universities. Clearly, both halves deserve attention. ${ }^{23}$

Indeed, most $(55-17=38)$ of our so-called rank-and-file universities still belong to the category labeled "research universities" under the standard Carnegie Classification. ${ }^{24}$ They contribute significantly to the research output.

23. Our two-pronged proposal in Section 10 calls for supporting top universities through block grants and rank-and-file universities through grants to individual researchers.

24. See Carnegie Foundation for the Advancement of Teaching (2001). Under that classification, the label "extensive research university" recognizes the granting of at least $50 \mathrm{PhD}$ degrees per year across 15 fields, irrespective of publication record. Some 150 universities-4\% of all institutions of higher education in the United States-qualify. Yet the requirement is minimal: for comparison, the Université Catholique de Louvain grants some $200 \mathrm{PhDs}$ per year. 
TABLE 6. Top economics departments.

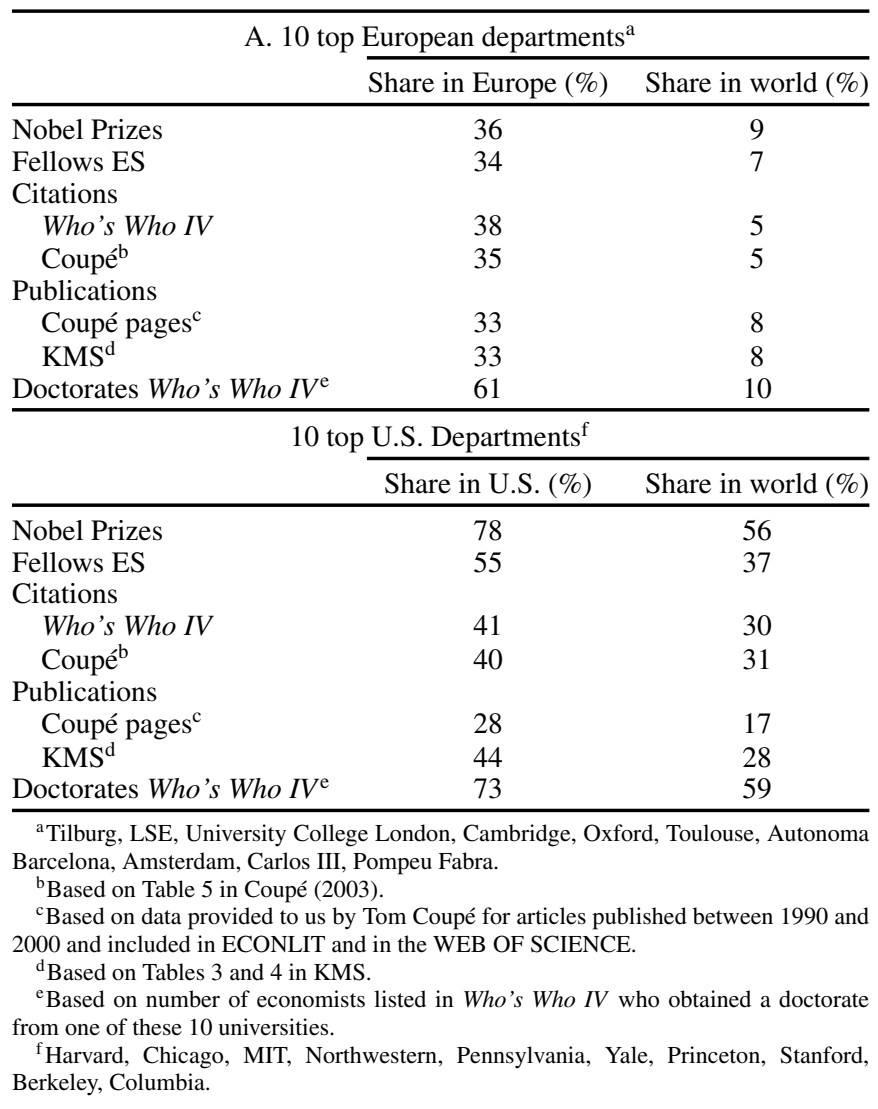

On that score, the rank and file rely upon top universities for scientific leadership as provided through training of faculty, temporary research positions (postdocs and sabbaticals), links to the scientific community, and so on.

Table 6 focuses on the place of the 10 leading departments in both regions. As usual, we note that the more selective measures entail both a larger share of top departments in the total and a wider gap between the United States and Europe. But it is noteworthy that the shares in citations and publications are similar in the two regions, confirming the similarity in degrees of concentration. ${ }^{25}$

According to LBKP, there exist 476 economics departments in the set of 12 countries made up by B4, S7, and UK. Only 118 (i.e., 25\%) among these house some (co)author of at least one article published between 1990 and 2000 in the top 30 journals selected by Kalaitzidakis, Mamuneas, and Stengos (2003;

25. Note, in the last rows of Tables $6 \mathrm{~A}$ and $6 \mathrm{~B}$, the exceptional weight of the top 10 universities in the training of researchers-a point of relevance to the previous paragraph and to Sections 8 and 10. 
TABLE 7. Europe's leading universities, and comparison with U.S.

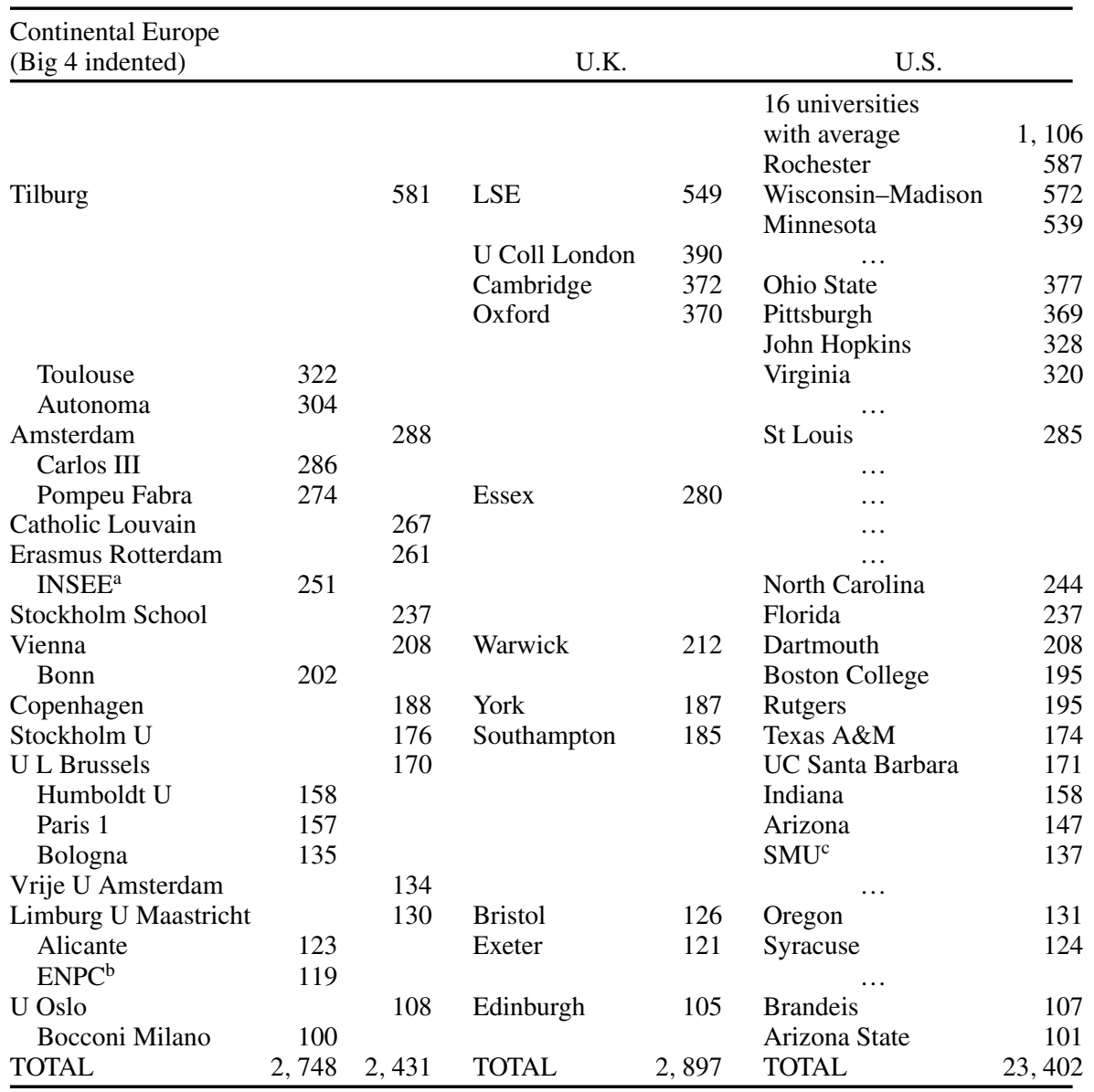

Notes: The figures denote numbers of pages as in KMS (Table 4).

${ }^{a}$ Institut National de la Statistique et des Etudes Economiques.

${ }^{\mathrm{b}}$ Ecole Nationale des Ponts et Chaussées.

${ }^{\mathrm{c}}$ Southern Methodist University.

hereafter KMS). ${ }^{26}$ Of these 118 departments, only 35 (i.e., 29\%) are listed as affiliation by (co)authors of at least 100 adjusted pages in the same 30 journals over the same decade; these departments are listed in Table 7. The list contains:

- 12 departments from S7 (5 from the Netherlands, 2 each from Belgium and Sweden, 1 each from Austria, Denmark and Norway);

- 12 departments from B4 (4 each from France and Spain, 2 each from Germany and Italy);

26. See Table 11 for the list of these journals and their "impact factors." 
- 11 departments from the UK (a mixed batch, ranging from the London School of Economics (LSE) to Edinburgh). ${ }^{27}$

We note that 29 among these also belong to the top 35 in Table 10 of LBKP. ${ }^{28}$ Table 7 also gives a selection of U.S. universities with comparable scores. Observe also that the 35 universities on our "short list" account for $75 \%$ of the total number of adjusted pages for 120 European universities (in Table 4 of KMS).

This relatively small set of universities pretty much carries the brunt of European research and higher education in economics today. Of course, every measure is imprecise, but adding a few entries (or omitting some) makes little difference overall. Rankings are not magical and should always be taken with a grain of salt. But the broad picture offered by Table 7 is solid. ${ }^{29}$

Not listed in the table are the 16 U.S. departments that do better than every European department, with an average score equal to twice the best European score. Some of these are scrutinized in Section 5. It is also interesting to look at the six U.S. departments (not listed in the table) that do better than every European department but not by more than 25\%: University of California-San Diego, University of Michigan, UCLA, Cornell, University of Texas, and Rochester. Emulating the likes of these is more realistic than emulating Harvard or MIT. That sobering prospect deserves further scrutiny on both sides.

\section{A Closer Look at Top U.S. Departments}

Table 8 collects selective data on 10 top U.S. departments. First comes the market value of the university's endowment. The figures are billions of dollars-yes, billions! Harvard leads with $\$ 25$ billion, a staggering figure that implies an annual endowment income of the order of a billion euros per year. (For perspective, this corresponds to the average annual budget of the European Research Council until 2013, a budget meant to stimulate overall research for 25 countries with a population of nearly half a billion citizens.) Other universities are not as rich, but their endowment is still measured in billions of dollars.

How does this wealth filter down to departmental opportunities? Columns 2 and 3 give a hint. The Harvard economics department (as distinct from the Business School, the Kennedy School, and so on) has 33 full professors, of whom 31 fill an endowed chair. It is known that much of Harvard's endowment is

27. The University of Geneva, with a score of 115 , also belongs on that list.

28. The remaining 6 entries in Table 7 are Bologna, Bristol, Alicante, Exeter, Edinburgh, and Bocconi.

29. A major limitation results from not taking into account departmental size. For instance, the European University Institute in Florence is absent from Table 7 for that reason alone. Clearly, size is critical to rankings of individual departments; on this point, see Section 4 of the Website version of Coupé (2003). For our purposes, the size bias is largely immaterial. 
TABLE 8. Faculty of top U.S. departments.

\begin{tabular}{lccccc}
\hline University & $\begin{array}{c}\text { University } \\
\text { endowment } \\
\text { (\$ billion) }\end{array}$ & $\begin{array}{c}\text { No. full } \\
\text { professors }\end{array}$ & $\begin{array}{c}\text { No. endowed } \\
\text { chairs }\end{array}$ & $\begin{array}{c}\text { PhD from top } \\
\text { 10 dept. }\end{array}$ & $\begin{array}{c}\text { No. years PhD } \\
\text { to first } \\
\text { appointment }^{\text {b }}\end{array}$ \\
\hline Harvard & 25 & 33 & 31 & $30 / 33$ & 11.5 \\
Chicago & 4 & 18 & 10 & $11 / 18$ & 9.6 \\
MIT & 7 & 25 & 14 & $21 / 25$ & 3.2 \\
Northwestern & 4 & 24 & 14 & $19 / 24$ & 9.4 \\
Pennsylvania & 4 & 15 & 8 & $7 / 14$ & 3.8 \\
Yale & 15 & 33 & 20 & $18 / 23$ & 8 \\
Princeton & 11 & 38 & 16 & $27 / 35$ & 11.6 \\
Stanford & 12 & 22 & 15 & $20 / 22$ & 6.3 \\
Berkeley & 5 & 47 & 16 & $33 / 42$ & 8.7 \\
Columbia & 5 & 25 & 11 & $19 / 24$ & 13.3 \\
Mean & 9.2 & 28 & 15.5 & $79 \%$ & 8 \\
\hline
\end{tabular}

\footnotetext{
${ }^{\mathrm{a}}$ The difference between the total number of full professors in this column and in the second column is due to missing information.

${ }^{\mathrm{b}}$ Averages, ignoring missing observations
}

earmarked for specific projects. In that category, endowed chairs are particularly flexible and immensely helpful to departments. It is no wonder that an economics department with 31 endowed chairs stands out as a world leader.

The exceptional hiring opportunities offered by such resources must, of course, be put to good uses. Where and how does Harvard recruit its faculty? Column 4 reveals that 30 out of 33 Harvard professors (of economics) obtained their PhDs at one of the 10 universities listed in Table 8. Column 5 reveals that, on average, these 33 professors were hired 11 years after completing their PhDs.

In other words, Harvard hardly takes chances: It hires people coming out of the best schools ${ }^{30}$ after their lasting merits have been tested elsewhere for eleven years! ${ }^{31}$ Picking the best is then possible thanks to the salaries and facilities associated with endowed chairs. All it takes is adoption of the right standards at the hiring stage. (Clearly, Harvard performs well on that score; its appointment policy deserves attention.)

The other rows of Table 8 are generally comparable to the first: a majority of full professors holding endowed chairs (except at the large public institution Berkeley); an overwhelming majority of professors coming from leading schools; and a substantial testing period after the $\mathrm{PhD}$. All this is a pipe dream for those of us who have coped with the anguish of attracting from outside, and keeping over time, first-rate scholars-sometimes in countries devoid of natural attraction and unable to match world salaries.

It is thus clear that emulating Harvard and other top U.S. universities is not within reach for Europe, a fact that we need not regard as dramatic. As suggested

30. "Coming out of" means in the first place that they were "admitted", a highly selective process. 31. For some information on initial appointments and their relation to career performance, see Oyer (2006) and Smeets, Warzynski, and Coupé (2006). 
before, our eyes should rather be directed at Michigan or Cornell, and it would be desirable to produce data comparable to those of Table 8 for universities in that category. Of particular interest would be an assessment of the means deployed by these universities. ${ }^{32}$ Although European universities may not expect funding on a scale comparable to that of top U.S. universities, they clearly need some additional means. How much might prove adequate is worth investigating.

\section{Where Are Economics Professors Educated?}

The next-to-last column of Table 8 is particularly instructive: it gives the proportion of the faculty at top U.S. departments trained at the same 10 leading schools: namely, $80 \% !^{33}$ Even if there is no inbreeding by individual universities, there is almost complete collective inbreeding by the small group of leading universities. It is thought-provoking that worldwide economic research is being pursued under the leadership of only a few hundred university professors trained and employed by a handful of U.S. departments. ${ }^{34}$

For comparison purposes, Table 9 collects some data on where members of leading European departments were trained. Two features are striking: the success of a few universities (namely, Pompeu Fabra, Carlos III, and Essex) in attracting faculty members trained abroad and the minimal presence of professors trained abroad at S7 universities. The latter feature is particularly striking in light of the research score of S7 departments; this deserves further scrutiny.

Another approach to tracing where economics professors are trained can be found in a paper by Amir and Knauff (2005, Table 1), from which our Table 10 is reproduced. That table reveals, for each member $j$ of a set of 54 universities, ${ }^{35}$ how many faculty members at the full set of 54 universities hold doctorates from $j$. Thus, the 10 U.S. universities in Table 6B and Table 8 have together trained 912 professors out of a total of 1,596 , or $57 \%$. In contrast, the 10 European universities in Table 6A have trained 144 professors, or $9 \%$.

The role of leading universities in the training of professors-to-be is thus fully confirmed ${ }^{36}$ and so is the contrast between the unified academic market in the United States and the fragmented European situation. These data quantify a commonplace observation: in the United States, concentration of talent at leading

32. For the universities mentioned at the end of Section 3, the endowment figures are Michigan, $\$ 4.2$ billion; Cornell, $\$ 2.6$ billion; Texas, $\$ 2$ billion; Rochester, $\$ 1.2$ billion, UCLA, $\$ 0.6$ billion; San Diego, $\$ 0.2$ billion.

33. Harvard and MIT together account for $47 \%$ of the total.

34. More on this in Section 7.

35. For construction of the set—starting from 30 world leaders and proceeding by cooptation — see Amir and Knauff (2005).

36. See also notes 25 and 31 . 
TABLE 9. Doctoral training of some European economists.

\begin{tabular}{lcccr}
\hline Affiliation & Coverage & \% same country & \% same university & \% U.S. \\
\hline Pompeu Fabra & $53 / 75$ & 21 & 2 & 40 \\
Essex & $24 / 26$ & 38 & 4 & 46 \\
Carlos III & $29 / 32$ & 38 & 0 & 41 \\
LSE & $14 / 25^{*}$ & 43 & 7 & 57 \\
Nottingham & $16 / 20$ & 56 & 0 & 31 \\
Maastricht & $14 / 28$ & 57 & 36 & 7 \\
U College London & $29 / 33$ & 59 & 10 & 17 \\
Aix-Marseille & $16 / 27^{*}$ & 63 & 25 & 13 \\
Amsterdam & $18 / 24$ & 67 & 44 & 11 \\
Copenhagen & $31 / 39$ & 68 & 55 & 3 \\
Stockholm School & $13 / 16^{*}$ & 69 & 31 & 15 \\
Tilburg & $14 / 18^{*}$ & 71 & 21 & 14 \\
Toulouse & $21 / 22$ & 71 & 48 & 10 \\
York & $40 / 46$ & 73 & 23 & 23 \\
Erasmus & $15 / 21$ & 73 & 53 & 13 \\
Vrije Amsterdam & $17 / 25$ & 82 & 24 & 6 \\
Cath. Louvain & $23 / 23$ & 87 & 65 & 4 \\
Stockholm U & $9 / 12$ & 89 & 0 & 11 \\
\hline
\end{tabular}

Note: Based on the Web sites of those departments for which the desired information proved readily accessible. Coverage reflects availability of information. An asterisk means "professors only"; the composition of the group is not otherwise identified, but its size is suggestive.

universities is permitted by the existence of a unified and transparent market for economists; no such market exists yet in Europe. ${ }^{37}$

The selective hirings by top U.S. departments are possible for the following reasons.

1. Professors are mobile across the country. Most realize that a first job may not be available at once in a top (and well-paying) department. Transfers to better departments require publications (i.e., research); the supply side of the market is thus flexible and governed by proper incentives.

2. Departments are competing with each other for hiring the best professors. The departments at top universities are able to offer better salaries and working conditions; thus the demand side of the market is competitive and qualityoriented.

Europe should aim at emulating these features.

\section{Reconsidering the Europe-U.S. Competition}

From the material reviewed so far, we conclude that the Lisbon objectives are not in sight for economics; still, there is scope for initiatives apt to reduce the U.S.Europe gap significantly (by a factor of 2) and perhaps even quite swiftly. But these initiatives call for accepting world standards of research performance-the

37. See Section 7(4). 
TABLE 10. Where university professors are trained.

\begin{tabular}{lclc}
\hline University & No. grads & University & No. grads \\
\hline Harvard U & 164 & U Paris 9 & 12 \\
MIT & 156 & European U Institute & $\mathbf{1 2}$ \\
Stanford U & 110 & U Autonoma-Barcelona & $\mathbf{1 2}$ \\
U Chicago & 106 & EHESS-Paris & $\mathbf{1 1}$ \\
UC-Berkeley & 98 & Duke U & 11 \\
Princeton U & 97 & Boston U & 11 \\
Yale U & 92 & Australian National U & 11 \\
Northwestern U & 89 & Purdue U & 10 \\
U Minnesota & 57 & New York U & 10 \\
LSE & $\mathbf{4 6}$ & Brown U & 9 \\
U Rochester & 40 & U Western Ontario & 9 \\
U Pennsylvania & 39 & Cal Tech & 8 \\
Oxford U & $\mathbf{3 5}$ & U Illinois & 8 \\
U Wisconsin & 35 & U British Columbia & 8 \\
U Michigan & 34 & U Toronto & 7 \\
U Louvain/CORE & $\mathbf{2 6}$ & UC-Davis & 7 \\
U Paris I & $\mathbf{2 5}$ & U College London & $\mathbf{6}$ \\
Cambridge U & $\mathbf{2 4}$ & U Pittsburgh & 6 \\
Columbia U & 23 & Pompeu Fabra U & $\mathbf{6}$ \\
UC-Los Angeles & 22 & U Washington & 6 \\
Cornell U & 22 & U Iowa & 6 \\
UC-San Diego & 18 & Rice U & 6 \\
U Toulouse & $\mathbf{1 6}$ & Penn State & 5 \\
Queen's U & 16 & U Maryland & 5 \\
Johns Hopkins U & 15 & U Virginia & 5 \\
Carnegie Mellon U & 14 & SUNY-Stony Brook & 4 \\
U Aarhus & $\mathbf{1 2}$ & U Carlos III-Madrid & 4 \\
\hline
\end{tabular}

Source: Based on Amir and Knauff (2005, Table 1, pp. 9-10).

Note: European institutions are in boldface.

very standards from which the gap's existence derives. The key question is, Should Europe adopt publications in top world journals as a measure of its own research performance in economics, or should Europe instead adopt its own standards of performance ? $^{38}$

1. A first aspect of the question concerns adoption of English as the working language of doctoral education and publications. We regard this as being absolutely necessary for progress on the Lisbon-EEA road. The main argument in favor of that option is that circulation of ideas and research results, both worldwide and within Europe, is enhanced by use of a single language as a vehicle of communication. With several languages, the users of minority

38. In private correspondence, David Colander has suggested to us that the latter alternative should be preferred. His case rests in part on the views that (i) journal editing practices are less objective than claimed and (ii) the role of journals in dissemination of knowledge is both limited and bound to decline in the future. We respect these views and invite readers to consider them. Though Colander may well prove right in the long run, we feel that the intermediate step advocated here cannot be dispensed with. 
TABLE 11. Leading journals and their authorship.

\begin{tabular}{|c|c|c|c|c|}
\hline Journal & $\begin{array}{l}\text { Impact } \\
\text { factor }\end{array}$ & $\begin{array}{c}\text { Europe } \\
(\%)\end{array}$ & $\begin{array}{l}\text { U.S. } \\
(\%)\end{array}$ & $\begin{array}{l}\text { Share of } 3 \text { main } \\
\text { universities }(\%)\end{array}$ \\
\hline American Economic Review & 100.00 & 8.4 & 82.0 & 13.27 \\
\hline Econometrica & 96.78 & 20.2 & 67.0 & $17.77^{\mathrm{a}}$ \\
\hline Journal of Political Economy & 65.19 & 10.8 & 80.4 & $18.95^{\mathrm{b}}$ \\
\hline Journal of Economic Theory & 58.76 & 23.3 & 57.3 & 9.89 \\
\hline Quarterly Journal of Economics & 58.11 & 11.4 & 84.5 & $32.86^{\mathrm{c}}$ \\
\hline Journal of Econometrics & 54.91 & 26.8 & 54.0 & 7.91 \\
\hline Econometric Theory & 45.85 & 36.5 & 41.9 & 12.8 \\
\hline Review of Economic Studies & 45.15 & 25.5 & 62.1 & 13.95 \\
\hline Journal of Business and Economic Statistics & 38.41 & 18.7 & 64.6 & 6.97 \\
\hline Journal of Monetary Economics & 36.41 & 11.8 & 73.8 & 12.69 \\
\hline Games and Economic Behavior & 35.49 & 31.7 & 50.8 & 11.65 \\
\hline Journal of Economic Perspectives & 34.26 & 6.3 & 91.3 & $20.32^{\mathrm{d}}$ \\
\hline Review of Economics and Statistics & 28.02 & 25.5 & 62.1 & 6.93 \\
\hline European Economic Review & 23.76 & 65.3 & 26.2 & 8.46 \\
\hline International Economic Review & 23.04 & 18.8 & 57.7 & 4.95 \\
\hline Economic Theory & 22.43 & 23.8 & 60.7 & 10.48 \\
\hline Journal of Human Resources & 21.34 & 8.7 & 83.0 & 9.58 \\
\hline Economic Journal & 20.71 & 60.6 & 30.6 & 11.23 \\
\hline Journal of Public Economics & 19.77 & 34.8 & 49.6 & 5.36 \\
\hline Journal of Economic Literature & 18.78 & 13.6 & 80.4 & 12.54 \\
\hline Economics Letters & 18.73 & 35.3 & 42.8 & 2.46 \\
\hline Journal of Applied Econometrics & 16.59 & 38.9 & 42.1 & 7.01 \\
\hline Journal of Economic Dynamics and Control & 14.54 & 31.8 & 53.2 & 6.4 \\
\hline Journal of Labor Economics & 12.76 & 10.8 & 71.9 & 9.35 \\
\hline Journal of Environmental Economics and Management & 11.85 & 14.1 & 74.7 & 10.03 \\
\hline Rand Journal of Economics & 11.44 & 16.2 & $\mathbf{7 5 . 6}$ & $15.07^{\mathrm{e}}$ \\
\hline Scandinavian Journal of Economics & 10.66 & 72.0 & 22.4 & 13.02 \\
\hline Journal of Financial Economics & 9.89 & 3.6 & 91.5 & $15.63^{\mathrm{f}}$ \\
\hline Oxford Bulletin of Economics and Statistics & 8.35 & 77.2 & 16.5 & 13.8 \\
\hline Journal of International Economics & 7.84 & 19.3 & 63.4 & 9.0 \\
\hline
\end{tabular}

Sources: Column 1 based on table 1 in KMS; columns 2, 3, and 4 based on data available at http://student.ulb.ac. be/ tcoupe/ranking.html.

Note: Bolface represents shares of $70 \%$ or more.

${ }^{a}$ Yale, Northwestern, MIT.

${ }^{\mathrm{b}}$ Chicago, MIT, Harvard.

${ }^{\mathrm{c}}$ Harvard, MIT, Chicago.

${ }^{\mathrm{d}}$ Harvard, Berkeley, MIT.

${ }^{\mathrm{e}}$ Harvard, Northwestern, Berkeley.

${ }^{\mathrm{f}}$ Harvard, Rochester, Pennsylvania.

languages are the losers: Their ideas do not circulate widely and do not receive the attention they deserve. Hence, we maintain that Europe should indeed opt for English as detailed in Section 2.1. Otherwise, stop paying lip service to Lisbon! On this aspect we have no qualms or reservations.

2. A second aspect of the question concerns acceptance of publications-cumcitations in international journals as a measure of research performance with the implication that incentives be provided on that basis to individuals and departments. 
For the 30 journals selected by KMS, Table 11 provides some information about the origins of contributors. If one defines "domination" by a share of $70 \%$ or more in authorship and "absence" by a share of less than 15\%, then Table 11 may be informally summarized as follows:

- Europe dominates 2 journals ${ }^{39}$ and the United States dominates 11 journals;

- Europe is absent from 10 journals and the United States from none;

- Europe's share exceeds 50\% in 4 journals, ${ }^{40}$ and the U.S. share exceeds $50 \%$ in 22 out of 30 journals. ${ }^{41}$

The list contains a number of journals that draw authorship from the world more or less in line with the geographical distribution of research output-that is, with approximately 20\% European and 60\% American authorship. (Examples include Econometrica, JET, and Review of Economic Studies.) The more such journals there are, the better for the circulation of ideas. Europeans should encourage the proliferation of such journals. ${ }^{42}$

The participation of Europeans among the 151 editors and co-editors for these 30 journals is likewise in line with the distribution of the research output: 40 (co-)editors are affiliated with a European university (20 in the UK, 13 in the S7, and 7 in the B4); 101 hold a U.S. affiliation.

We do not attach particular significance to the precise KMS selection or weights; in fact, we would recommend a broader set. ${ }^{43}$ But we conclude that the proper way for Europe to influence world standards at this time is to work within the system and to gain weight in the process through increased research efforts. In our opinion, it would be extremely dangerous and counterproductive for Europe to set itself outside of the accepted world channels of research evaluation and dissemination. The relative performance of economists in the B4 illustrates where such an approach might lead.

\section{Scandinavian Journal and Oxford Bulletin.}

40. Same plus European Economic Review and Economic Journal.

41. Among our journals it is rare to have authorship concentrated at a few universities. The clearest case is the Quarterly Journal of Economics, for which one-third of the articles are written at Harvard, MIT, or Chicago. (For the Journal of Political Economy, the same universities contribute 19\%.) Otherwise, authorship from a single university rarely exceeds $5 \%$; no university contributes a full $1 \%$ to Economics Letters or $2 \%$ to International Economic Review. No European journal has concentrated authorship. The Scandinavian Journal receives 13\% of published contributions from Oslo, Stanford, and Bergen; the UK-based Review of Economic Studies receives 14\% from MIT, Northwestern, and Harvard!

42. The American Economic Association has recently announced its intention to start four new journals. Currently, the AEA publishes three journals: AER with $82 \%$ U.S. authorship, JEP with $91 \%$, and $J E L$ with $80 \%$ (Table 11). In other words, AEA journals are "domestic outlets." It would have been desirable to consider AEA-EEA joint sponsorship of the new journals. As a second best, it would be desirable for the editorship of each new AEA journal to include foreigners.

43. Using the 68 journals selected by LBKP and weighted less selectively leads to unchanged conclusions. 
This conclusion is based on (i) the recognition that scientific progress is a world undertaking that should be guided by common world standards and (ii) the belief that progress in Europe is at hand and will be conditioned by adopting the right incentives as defined by world standards of quality. Any other approach strikes us as being doomed to failure. (Of course, this is a personal opinion that remains open for discussion.)

3. A third aspect of the question concerns the role of incentives in the organization of teaching and research-including the "publish or perish" dilemma. Today, careers at the better universities call for early establishment of a suitable publication record.

This has some clear drawbacks, of which the most important is perhaps the bias in favor of quickly publishable research versus projects requiring a more prolonged effort (as required, for example, to construct data sets). Various systems for incentives and/or promotions now exist in different countries, and it is increasingly possible to evaluate them. In the meantime, experimenting with alternatives is desirable. If superior alternatives to "publish or perish" can be devised, so much the better. Experience also suggests that implementing incentives while boosting morale is possible in departments where due attention is paid to the human side of our profession.

A further issue related to incentives concerns the dual roles of motivation and selection. At the individual level, incentives provide motivation to publish. At the level of departments, publication records guide the selection of new members. This selection process does not boost output directly. The ultimate individual motivation comes from hiring prospects in the early years and from promotion or salary bonuses later on. Incentives motivating young members of rank-and-file universities are important, as advocated in Section 10.

4. Despite all this, we remain a long way from an integrated market for academic economists in Europe, and fail thereby to replicate a feature that seems important to the U.S. performance. Many aspects of this issue lie beyond the scope of this paper, because they bear on job opportunities for spouses, schooling, living conditions, and the like. One aspect that deserves scrutiny concerns salary competition across countries. The principle that national legislations should not prevent matching offers from other European countries has definite appeal and deserves scrutiny or initiatives. Another aspect, stressed in particular by Mas-Colell (2003), concerns career patterns. The uniform practice of granting tenure some six years or so after the $\mathrm{PhD}$ generates a level field on which all U.S. universities operate. In Europe, career patterns differ across countries, which reduces international mobility. Still, a number of recent initiatives contribute to the transparency of the EU academic market. One of these came about recently when the EEA took over the European Job Market Web 
TABLE 12. U.S. doctorates (by deciles).

\begin{tabular}{cccc}
\hline $\begin{array}{l}\text { Percent of } \\
\text { doctorates }\end{array}$ & No. universities & Cumulative & $\begin{array}{c}\text { Minimal no. of doctorates } \\
\text { per university per year }\end{array}$ \\
\hline 10 & 3 & 3 & 32 \\
20 & 5 & 8 & 23 \\
30 & 5 & 13 & 20 \\
40 & 7 & 20 & 16 \\
50 & 8 & 28 & 12 \\
60 & 10 & 38 & 9 \\
70 & 13 & 51 & 8 \\
80 & 17 & 68 & 6 \\
90 & 22 & 90 & 1 \\
99 & 36 & 126 & $<0.1$ \\
100 & 41 & 167 & \\
\hline
\end{tabular}

Note: Based on the average number of doctorate recipients in the period 1994-2003.

Universities by deciles:

1. Berkeley, Chicago, Harvard.

2. Illinois, MIT, Stanford, Wisconsin, Cornell.

3. Pennsylvania, Minnesota, Yale, Maryland, Ohio State.

4. Michigan State, Columbia, UCLA, Texas A\&M, Princeton, Northwestern.

5. Purdue, NYU, Ann Arbor, Rochester, UC Davis, Texas, Penn State, Missouri.

Source: National Science Foundation Web CASPAR (http://webcaspar.nsf.gov/).

site initially started by the Spanish Economic Association. Other comparable initiatives concern finance or the placement of current graduates. ${ }^{44}$

\section{Doctoral Programs}

Which universities produce PhDs in the United States and Europe? Basic information is summarized in Table 12 for the 1,106 doctorates per year awarded (on average, over the decade 1994-2003) by 167 U.S. universities.

Drèze (2001, Section 2) alludes to some inefficiencies of U.S. doctoral programs in economics. One major deficiency is the small size of most programs. As aptly stated by Cremer and Gérard-Varet (1999), "doctoral programs should be large enough that students can collaborate with each other and find intellectual support from their peers.” But where does an efficient size start? In the 1990s, the National Research Council (1995) scored the effectiveness of all U.S. graduate schools on a scale of 1 to 5 . Only 26 programs received a score of 3 or more; these granted on average 17.5 degrees per year in 1992 and 1993. According to Table 12, only 28 U.S. universities run programs graduating 12 or more doctors per year, with an average of 20 degrees. These 28 universities together grant half the U.S. degrees. It thus seems reasonable to place a lower limit on efficient size somewhere between 12 and 20 graduates per year-say, $16 \pm 4$. But half of the U.S. degrees are awarded under programs that are inefficiently small, graduating

44. See www.eeassoc.org, www.europlace-finance.com, and www.adres.polytechnique.fr. 
TABLE 13. Doctorates granted by some European universities, 1994-2003.

\begin{tabular}{lc}
\hline University & No. doctorates \\
\hline Paris 1 & 650 \\
Oxford & 219 \\
Toulouse & 206 \\
Autonoma & 169 \\
Cambridge & 161 \\
European University Institute & 160 \\
Erasmus Rotterdam & 129 \\
Tilburg & 128 \\
Warwick & 126 \\
Catholic Louvain & 109 \\
Carlos III & 108 \\
U Coll London & 84 \\
Amsterdam & 80 \\
Vrije U Amsterdam & 79 \\
Stockholm School & 62 \\
Limburg U Maastricht & 62 \\
Pompeu Fabra & 60 \\
U Oslo & 59 \\
Essex & 58 \\
Southamptom & 57 \\
U L Brussels & 54 \\
Bonn & 51 \\
\hline
\end{tabular}

fewer than 12 students per year. And nearly half of the programs (77 out of 167) are dwarfs, producing fewer than 4 doctors per year.

One may wonder why a university would offer doctoral training, which is costly, to such inefficiently small cohorts. Hypotheses range from prestige and hiring opportunities to use of doctoral students as teaching or research assistants. Whatever the reason, few colleagues associated with dwarf programs would consider giving up doctoral training. This point deserves further consideration.

Data comparable to those in Table 12 are not readily available for Europe. However, see Table 14 (and comments) in Kirman and Dahl (1996) while realizing that immense differences prevail in the quality of European doctorates. In an attempt to remedy the data deficiency, we asked colleagues at universities listed in Table 7 to supply comparable data. The information so collected is presented in Table 13.

The first entry in Table 13 is challenging: with 65 graduates per year, Paris I is perhaps the university with the largest doctoral program in economics worldwide! How should one interpret this observation? It is of course tempting to simply disregard it on the grounds that it must reflect less exacting requirements than at the other universities considered here. Such dismissal would be too easy and definitely unfair. Thus, in Table 10, Paris I occupies an enviable yet plausible 
place as the fourth most significant training center in Europe. Pending further probing, we focus on the rest of the table.

Our scanty data cover a few universities with a $\mathrm{PhD}$ program comparable in size to those of the 20 major U.S. universities in Table 12-namely, 16 graduates per year or more. Next comes a small group with 10 to 12 graduates per year. Half our answers concerns programs with 5 to 8 graduates per year. Hence there is some way to go before leading European $\mathrm{PhD}$ programs in economics reach an efficient size. Further concentration seems worth encouraging, especially if English becomes the working language. ${ }^{45}$

Another deficiency of U.S. doctoral training stressed in Drèze was "isolation," about which he wrote: "The isolation has two aspects. First, students do not move; they do all their graduate work at a single institution, and thus deprive themselves of the benefit of exposure to alternative views. Second, university departments hardly co-operate in education with other economics departments located nearby" (2001, p. 6; emphasis in original).

This is one area where Europe has an edge, thanks to initiatives along three avenues of cooperation.

1. International joint ventures by universities in several countries, whereby students are invited to attend at least two universities as part of their degree. This gives students access to a wider pool of talent for courses and thesis supervision, and it forces them to come in contact with two different departments and university systems. Well-known examples are EDP and ENTER. ${ }^{46}$

2. National ventures under which advanced courses are offered at the national level and are attended by students from all the universities in the country. The students benefit from inter-university contacts and the participation of the better teachers (often foreigners) for each subject. Some courses are intensive residential sessions over short periods; others are offered on a weekly basis. This works more easily in small countries like the Netherlands (NAKE program) or Switzerland.

3. Local joint ventures by neighboring universities that offer complementary advanced courses attended by students from all participating universities. Examples are the Tinbergen Institute, a joint venture of three universities; the doctoral school of French-speaking Belgium (three universities); and

45. An ancillary issue that might well prove significant concerns the place of $\mathrm{PhD}$ programs in the new "Bologna" structure (the 3-5-8 or bachelor-master-PhD sequence). In the U.K.-U.S. tradition, years 4 and 5 correspond to the course work for a PhD. In several continental countries, "doctoral schools" start after the 5-years master's degree. Proper attention should be paid to informing student across national borders.

46. See www.edp-site.net and www.enter-program.com. 
the brand-new Barcelona Graduate School of Economics (Autonoma and Fabra). ${ }^{47}$

With up to thirty years of experience for these ventures, it would seem appropriate to attempt a systematic objective evaluation of benefits reaped and problems faced. Such ventures are indeed a potential answer to the scale problem.

\section{Funding Doctoral Training and Research}

Drèze stresses "the difficulties associated with three specific features of graduate training seen as an economic activity, namely:

1. Research output is a pure public good and graduate teaching is typically a public good with exclusion;

2. Graduate education is an activity subject to increasing returns to scale, up to a program size rarely exceeded;

3. Graduate education is a good subject to substantial variations in product quality.

These three features, in isolation and a fortiori in conjunction, imply that decentralised supply is generically not efficient, or even constrained-efficient, unless incentives are suitably designed. Abdessalem (1997) investigates the provision of public goods with exclusion, produced under increasing returns, and applies his theoretical results to university education. Assuming that universities charge second-best tuition fees, and taking social as well as private returns into account, Abdessalem finds that public support of universities should come in three forms: (i) block grants to institutions; (ii) grants per graduating student, differentiated by fields of study; and (iii) positive or negative block grants to programs of study. The negative grants to programs are precisely meant to prevent the proliferation of undersized programs. They do not seem to exist anywhere" (Drèze 2001, pp. 4-5; emphases in original).

That lengthy quotation was needed to document the second-best efficiency of block grants to programs of study (e.g., doctoral programs in economics). ${ }^{48}$ There is more to the theme, however. Thus, it is suggested in Drèze (2001) that tuition fees should be raised in those countries where they are minimal. ${ }^{49}$ More broadly, the whole issue of funding of $\mathrm{PhD}$ programs in Europe requires investigation.

47. In Table 7, pooling the member universities brings the Tinbergen Institute to the top (with a score of 683), the Barcelona GSE to third place (578), and Louvain-Brussels to fifth place (437).

48. Understandably, we ignore the negative grants to undersized programs!

49. European EDP students face tuition fees of $€ 9,000$ at Pompeu Fabra (with many scholarships), $€ 3,168$ at LSE, $€ 778$ at Louvain-la-Neuve, $€ 385$ at Paris, $€ 300$ at Bonn, and $€ 0$ at European University Institute. 


\section{A Two-Pronged Proposal}

In order to enhance the research performance and teaching efficiency of European universities, we propose here two programs that are addressed (respectively) to the demand side and the supply side of a European market for academic economists. Our proposal naturally starts from the premise that maintaining and strengthening the activities of leading economics departments in Europe is essential to further progress. Toward that end, we recommend block grants to leading departments. We realize (from Section 4) that rank-and-file departments matter just as much, but these would be candidates for negative block grants! Therefore, we suggest providing research incentives to individuals across the institutional spectrum. The market considerations and the second-best considerations thus reinforce each other.

Should this fresh funding be appropriated at the national level or at the EU level? Given the small number of potential recipients for the block grants (about one per EU member state), competition among the applicants unequivocally calls for EU-level appropriation. But systematic matching of European grants from national sources would be desirable, since this would spread the costs between EU-level funds (a scarce resource) and national funds.

Given that funds are scarce, it is essential that they be used with maximal efficiency. Our best advice on that score is simply to allocate funds according to research merits and then let beneficiaries decide how best to use them.

\subsection{The Demand Side}

We start with doctoral training in economics in Europe. It is clear that the elite of European economists should be trained at first-rate graduate schools operating $\mathrm{PhD}$ programs of efficient size. A natural upper bound to the number of such schools lies somewhere around 30; we offer the list in Table 7 as a starting point, one that is naturally open to some modifications.

Clearly, our leading schools would benefit greatly from some additional funding (some: not 30 endowed chairs!), especially funding available for whatever use the schools would favor-that is, funding with no strings attached. Experience with the management of research confirms unequivocally the benefits of some freedom in resource allocation, in particular to attract and accommodate foreign teachers-researchers.

To be concrete, we suggest organizing a fund for block grants to major $\mathrm{PhD}$ programs that is able to offer some 20 to 30 grants of $€ 300,000$ to $€ 500,000$ per year on a competitive basis across the EU. ${ }^{50}$ The grants should come in

50. We regard these somewhat arbitrary amounts as minimal. To repeat, funding of graduate schools deserves further investigation. 
4- to 5-year installments and with no strings attached to their use. Appropriation criteria should be based solely on achievements, but eligibility would be restricted by three conditions:

1. The language of instruction should be English.

2. The program should be of sufficient size, meaning at least 10 or $12 \mathrm{PhDs}$ per year on a moving average basis.

3. The department should have a strong record of published research in a limited set of journals weighted by impact factors.

We address in what follows the tricky question of organizing the selection of beneficiaries of these grants. Importantly, such a program should automatically support research at centers of excellence across Europe.

The suggested amount of the grants is designed to make a difference while recognizing that resources transiting through the EU budget are scarce. ${ }^{51}$ The annual cost of this program would be of the order of $€ 10$ million to be shared between European and national budgets. This amount could be phased in over a few years. Given that few programs today meet our three conditions, a progressive approach is appropriate.

\subsection{The Supply Side}

In order to promote the supply of a flow of young research-oriented economistswhether employed by leading universities or (more significantly) by rank-andfile institutions-we suggest organizing a fund for block grants to productive young academics that is able to offer some 200 grants of $€ 25,000$ per year on a competitive basis across the EU.

These grants also should come in 4- to 5-year installments with no strings attached to their use. Appropriation criteria should be based solely on research achievements (meaning publications in good journals), but eligibility would be restricted by three conditions:

1. The applicants should be younger than 45 years old.

2. The applicants should work full-time for a university or research center.

3. The applicants should not also hold nonacademic jobs during the period of support.

One important set of potential candidates consists of Europeans working abroad. The EU already offers special grants aimed at facilitating the return to Europe of emigrated scientists.

51. The suggested amounts also correspond to the tuition fees that would be collected from some 100 doctoral students at an annual rate of $€ 3,000$ to $€ 5,000$. This remark opens the door to an alternative funding program. 
By "no strings" is here meant that beneficiaries could freely decide whether to use the grants for supplements to personal income, for research expenses or assistance, to buy back a reduced teaching load, or whatever.

The amount of $€ 25,000$ is chosen to offer the possibility of a supplementary income that makes full-time academic activity feasible to all and, it is hoped, attractive to many. The annual cost of this program would be of the order of $€ 5$ million.

\subsection{Implementation}

We are thus asking for:

1. Fifteen million euros per year, divided between the European fund and national matching grants, with a phase-in period.

2. Acceptance of concentration of the institutional grants on a small number of centers of excellence operating in English.

3. Acceptance of the "no strings" principle both for institutions and for individuals.

4. Adoption of clear quality standards as exclusive selection guides.

None of these requests seems outrageous, but neither are they easy to implement; finding ways of meeting them will require some imagination.

With respect to item 1, note that our budget is probably the same order of magnitude as the full cost of economics at the European University Institute. It should also correspond to some $15 \%$ of a natural share of economics in the 6th Framework Programme or to half (or less?) of a natural share of economics in the annual resources of the recently established European Research Council. The budgetary issue is thus not paramount; but the institutional road to such a budget may be difficult to map. ${ }^{52}$

Regarding item 2, it is clear that a departure from the current approach to EU support of research is called for. Currently, international cooperation is the basic requirement for EU support-a reflection of the subsidiarity principle. Our case for a EU fund supporting centers of excellence is different: They would each operate at a European level, and there should be international competition among them. We regard this partial reorientation of EU-level funding principles as a clear lesson from an operational approach to the Lisbon program. And we invite

52. Another way to look at the budgetary issue would start from the existing support of research and doctoral training in economics through EU funding. This would include doctoral and postdoctoral fellowships (e.g., Marie Curie grants), grants to research networks, the research units in some directorates of the EU staff (ECFIN, Competition, etc.), research contracts from the same, and economics at the EUI. One could then compute what share of this total is represented by our request, a share that we would label as "the share of fundamentals in total support." If that share is moderate (say, about $15 \%$ ) then a case could be made that resources should be partly redirected toward this "fundamental" support if the Lisbon goals are to be taken seriously. Unfortunately, no figures are readily available on existing support as just defined. Collecting such figures would be highly desirable. 
the new European Research Council, which is not subject to such constraints, to innovate without hesitation.

Of these requests, the most difficult to meet in practice is probably the fourth one. There is now a record of European-level management of research support to economics covering a 20-year span. And there are many national bodies with extensive experience in funding research (from NSF in the United States to SSRC and the HEFCE in the United Kingdom). We suggest that implementing item 4 should be the subject of a research project that could be commissioned, for instance, by the EEA. In the meantime, we suggest adopting the criterion of current publications in top journals as a guideline. This might take the form of basic grants to all departments with high scores in such rankings as our Table 7 as well as supplementary grants to departments that are progressing in these worldwide rankings.

\section{Summary and Conclusion}

A number of specific conclusions and recommendations have emerged from our discussion of readily available data. But such data remain scanty. More research is needed on almost every point discussed here. We invite the EEA to promote such research in the same way that it did earlier for rankings of economics departments. ${ }^{53}$

Here is a concise summary of the information collected in this paper.

1. At this time, the United States occupies a leading position on the scene of research and $\mathrm{PhD}$ education in economics, with a published research output several times that of Europe (see Table 1); catching up with the United States will require a major effort and some time.

2. There is no evidence of a trend in the extent of the E.U.-U.S. gap, but there is some degree of brain drain (Table 2).

3. Europe is not homogeneous: The United Kingdom and several smaller European countries are well ahead (per capita) of the B4 continental countries (Table 5). The accomplishments in the United Kingdom and small countries bear witness to the possibility of progressively catching up with the United States. The concentration of research in leading departments is substantial but not exclusive; in both the United States and the European Union, some 20 departments account for about half the publications (Figures 1 and 2).

4. Some 35 European departments of economics, accounting for three quarters of the research output, are easily identified (Table 7); their long-run performance is essential to the process of catching up.

53. We welcome the timely decision by the EEA at its 20th Congress in Vienna to set up a Standing Committee on Research. The suggestion in the text is respectfully submitted to the attention of that committee. 
5. The top 10 U.S. departments rely extensively on endowed chairs to attract the best available faculty members (Table 8); $80 \%$ of their faculty come from the same 10 universities. In Europe, some universities hire internationally (especially the leading Spanish and some British universities), but universities in the small countries hire locally (Table 9). We are still far from an integrated European market for academic economists.

6. Doctoral programs reach an efficient size (16 \pm 4 graduates per year) at 20 to 28 U.S. universities (Table 12), but at only a handful of European universities (Table 13). Undersized programs still prevail on both scenes. Further concentration is very much called for in Europe.

On the basis of this information, we have drawn the following conclusions.

1. Acceptance of English as the lingua franca of economics is unavoidable today. This remark applies both to instruction in $\mathrm{PhD}$ programs and to publications, including the better national journals.

2. Institutional reforms, oriented towards providing the right incentives and rewards (to published research for individuals and to quality for departments), are urgently needed in the B4 continental countries.

3. Second-best funding of higher education and research calls for block grants to centers running major $\mathrm{PhD}$ programs and displaying proficiency in research. Providing such funding to a limited number of centers calls for an EU-level allocation process, but EU-level resources are quite scarce.

4. We propose a two-pronged EU-level program combining block grants to a limited number of "centers of excellence" with a larger number of grants to young individual researchers across Europe. This will stimulate both the demand side and the supply side of the emerging academic market. An annual budget of some $€ 15$ million is at stake. The allocation should be based on research accomplishments alone and be subject to specific eligibility conditions, but no strings should be attached to the uses of the grants.

5. These efforts may call for departing from some current EU practices. Unless we are willing to innovate, we shall not be able to implement the Lisbon program and the aims of the EEA.

6. Though the Lisbon objective is not in sight, major progress is possible if the relevant measures are enacted.

\section{Appendix A: Measuring Research Output}

Attempting to measure research output is a tricky task that is fraught with many pitfalls. There is room for two distinct aims: tracking excellence and tracking research activity. 
1. If concerned with excellence, one would ideally like to evaluate the "weight of ideas" contributed by original research-a qualitative rather than quantitative indicator. One practical way of tracing that elusive concept is to look at awards designed to recognize significant contributions to a discipline. For economists, two forms of public recognition of research merits are readily available: Nobel Prizes and fellowships of the Econometric Society. Although the latter are more specialized (there is a clear bias toward formal theory and quantitative methods), the bias is of ancillary relevance to international comparisons. These two indicators are reported in Table 1 and are, by nature, quite selective. $^{54}$

2. The more common measures of research output used in the literature are based on publications and/or citations. In principle, citations come closer to assessing "weight of ideas" than publications and so provide a more selective indicator.

However, attention must be paid to the time dimension of these indicators. Citations gain in significance when they are tabulated over a longer period, thus measuring the lasting value of contributions. Over a short interval following publication, citations reflect more the extent to which publications are in line with current trends, a different concept altogether. A choice between citations and publications thus also depends upon whether one aims to measure a stock (for which citations over a longer period are appropriate) or rather a flow (for which recent publications are more appropriate). A 10-year period seems adequate for a flow measure.

3. Whether one relies on citations or publications, an important decision concerns the publication outlets over which data are collected. In economics, journal articles are the standard basis. Two types of measures have been used, depending upon the base of journals:

- A broad set of journals is provided by either the ECONLIT data base, covering some 680 journals (including many journals with national audience), or the SSCI/WEB OF SCIENCE data base, covering some 200 journals.

- Narrower sets of "top journals" have been constructed by authors aiming to trace quality as well as quantity; typically, the authors also use weights to reflect journal quality.

Reliance upon top journals, the more elitist approach, comes closer to the "weight of ideas" concept and is used repeatedly here. Two sets of top journals are used: KMS, consisting of the 30 journals listed in Table 11; and LBKP, consisting of 68 journals (details are supplied in these two sources). The first set of 30 journals

54. The word "selective" was preferred by a referee to our original "elitist". Two notions are at stake: emphasis on the weight of ideas and on excellence, yet it is difficult to capture both notions with a single adjective. Ruiz-Castillo (2006) uses the term "egalitarianism" to denote "lack of selectivity." 
is, of course, a subset of the second set of 68. The fuller set of ECONLIT/WEB OF SCIENCE journals is used in some tabulations of Coupé.

4. A further dimension of the measurement issue concerns the basis for reporting data: either by departments or by individuals. Because much attention has been paid in the literature to ranking departments (a goal of ancillary relevance to our own pursuit), data are often aggregated over members of university departments or research centers. Although this should not matter in principle for comparison purposes, it does in fact matter some because the grouping of individuals into departments may vary between countries. (This is vividly illustrated by the situation in Paris: Of the 23 fellows of the Econometric Society giving an address or affiliation there, only 2 mention a university affiliation!)

5. When comparing the performance of departments, their size should (in principle) be taken into account: more members publish more. Because we are not concerned here with rankings, we need not introduce corrections for size. But readers playing the rankings game should bear that dimension in mind. ${ }^{55}$

The messages from different measures are largely congruent but are not identical. Reliance on several measures is thus desirable when drawing major conclusions.

There remains the issue of national or language bias in the editorial process of journals. We commented on that issue in Section 7, item 2.

\section{Appendix B: Sources}

ECONLIT covers some 680 economics journals and includes many national journals in national languages.

SSCI and WEB OF SCIENCE cover some 200 economic journals.

Who's Who in Economics (vols. II-IV); see Blaug $(1986,1999)$ and Blaug and Vane (2003). Each volume concerns those economists with the highest number of citations in the SSCI database for articles published during a specific period-that is, 1972-1983, 1984-1996, and 1990-2000, respectively. The numbers of entries for economists alive at time of publication are approximately 900, 1,000, and 750, respectively. 56

Coupé refers to data in Coupé (2003) or available on the Web site of Tom Coupé (http://student.ulb.ac.be/ tcoupe/ranking.html). All data are based on articles published in the years 1990-2000 in ECONLIT journals that are also covered by the WEB OF SCIENCE or on citations thereof. Data for departments come

55. See also note 29 .

56. It is interesting to note that average age (at time of publication) drops from 60 in edition III to 49 in edition IV. 
from Table 5 in Coupé (2003), which covers 200 departments worldwide; data for economists comes from Coupé's "ranking page".

HABM refers to data from Hirsch et al. (1984) or its update by Coupé (2003, Table 4). The original data are based on articles published in the years 19781982 in 24 "top journals"; the update pertains to years 1996-2000 and to the same journals. The data are assembled by departments.

KMS refers to data from Kalaitzidakis, Mamuneas, and Stengos (2003). These data are based on articles published in the years 1990-2000 in a weighted set of 30 top journals (listed in Table 11); they are assembled by departments.

LBKP refers to data from Lubrano et al. (2003), Table 10. These data are based on articles published in the years 1990-2000 in a weighted set of 68 top journals (listed in Table A.1 of the quoted paper) and are assembled by departments.

\section{References}

Abdessalem, Tahar (1997). Biens publics avec exclusion. Monographies d'Econométrie, CNRS, Paris.

Amir, Rabah, and Malgorzata Knauff (2005). "Ranking Economic Departments Worldwide on the Basis of PhD Placement." CORE Discussion Paper 2005/51, Louvain-la-Neuve.

Blaug, Mark (1986). Who's Who in Economics, 2nd edition. Wheatsheaf.

Blaug, Mark (1999). Who's Who in Economics, 3rd edition. Elgar.

Blaug, Mark, and Hal R. Vane (2003). Who's Who in Economics, 4th ed. Elgar.

Carnegie Foundation for the Advancement of Teaching (2001). The Carnegie Classification of Institutions of Higher Education. Carnegie Publications, Washington.

Coupé, Tom (2003). "Revealed Performances: Worldwide Rankings of Economists and Economics Departments, 1990-2000." Journal of the European Economic Association, 1, 1309-1345. Available at http://student.ulb.ac.be/ tcoupe/ranking.html.

Cremer, Jacques, and Louis-André Gérard-Varet (1999). "Doctoral Programmes in Economics in a European Context." Université Toulouse 1. Downloadable from www.univ-tlse1.fr/ MPSE/DPEEC.html.

Drèze, Jacques H. (2001). "Economics and Universities in Europe." Working paper, CORE. Downloadable from www.core.ucl.ac.be/staff/biosketchdreze.html.

European Commission (2004). Mapping of Excellence in Economics. Directorate General for Research, EUR 20889.

Hirsch, Barry T., Randall Austin, John Brooks, and J. Bradley Moore (1984). "Economics Departmental Rankings: Comments.” American Economic Review, 74(4), 822-826.

Kalaitzidakis, Pantelis, Theofanis P. Mamuneas, and Thanasis Stengos (2003). "Rankings of Academic Journals and Institutions in Economics." Journal of the European Economic Association, 1, 1346-1366.

Kirman, Alan, and Mogens Dahl (1996). Economic Research in Europe (Monograph in Economics). European University Institute, Florence.

Lubrano, Michel, Luc Bauwens, Alan Kirman, and Camelia Protopopescu (2003). "Ranking Economics Departments in Europe: A Statistical Approach." Journal of the European Economic Association, 1, 1367-1401.

Mas-Colell, Andreu (2003). "The European Space of Higher Education: Incentives and Governance Issues." Rivista di Politica Economica, 93(11-12), 9-27.

National Research Council (1995). Research Doctorate Programs in the United States: Continuity and Change. National Academy of Sciences, Washington. 
Oyer, Paul (2006). "Initial Labour Market Conditions and Long-term Outcomes for Economists." Journal of Economic Perspectives, 20, 143-160.

Ruiz-Castillo, Javier (2006). "Economic Research in Spain During the 1990s: A Literature Review.” Working Paper No. 06-36, Universidad Carlos III de Madrid.

Smeets, Valerie, Frederic Warzynski and Tom Coupé (2006). "Does the Academic Labour Market Initially Allocate New Graduates Efficiently?" Journal of Economic Perspectives, 20, 161-172.

Zipf, George K. (1949). Human Behaviour and the Principle of Least Effort. Addison-Wesley. 